\title{
Metal-catalyzed uncaging of DNA-binding agents in living cells $\uparrow$
}

\author{
Mateo I. Sánchez, Cristina Penas, M. Eugenio Vázquez* and José L. Mascareñas* \\ Attachment of alloc protecting groups to the amidine units of fluorogenic DNA-binding bisbenzamidines or \\ to the amino groups of ethidium bromide leads to a significant reduction of their DNA affinity. More \\ importantly, the active DNA-binding species can be readily regenerated by treatment with ruthenium \\ catalysts in aqueous conditions, even in cell cultures. The catalytic chemical uncaging can be easily \\ monitored by fluorescence microscopy, because the protected products display both different emission \\ properties and cell distribution to the parent compounds.
}

Received 3rd December 2013

Accepted 30th January 2014

DOI: $10.1039 / c 3 s c 53317 d$

www.rsc.org/chemicalscience

transition metal catalysts. Curiously, despite the extensive use

\section{Introduction}

A major research goal in chemical biology is the efficient and selective targeting of double stranded DNA with small molecules. Towards this goal, a wide range of synthetic DNA binders, from small molecules to larger peptides, have been developed over the years. ${ }^{1}$ In addition to the search for better sequence selectivity, ${ }^{2}$ there is also an increased focus on the external control of the DNA binding of these molecules, so that they can be activated when and where required at will. ${ }^{3}$ In this context, we have recently described a photo-uncaging strategy for controlling the non-covalent DNA interaction of DNA-binding agents, such as those shown in the Fig. $1{ }^{4}$

Although irradiation with light represents a clean and simple way of activating molecules in a spatiotemporally controlled way, the potential biological application of the strategy is limited by the low penetrability of the UV light typically used for photolysis and the likely secondary damage to the tissues. Other alternatives for the generation of bioactive agents in an externally controlled manner are therefore highly desirable. Particularly appealing is the possibility of releasing the active molecules by using a catalytic reaction that could be performed, for instance, by specific enzymes. ${ }^{5}$ Although the use of naturally occurring biocatalysts is attractive, its scope is intrinsically limited to a relatively small number of transformations and to compounds that could be recognized as substrates by the enzymes. A promising alternative to enzymes could be the use of

Departamento de Quimica Orgánica e Centro Singular de Investigación en Química Biolóxica y Materiais Moleculares (CIQUS), Universidade de Santiago de Compostela, 15782 Santiago de Compostela, Spain. E-mail: joseluis.mascarenas@ usc.es; Tel: +34881814405

$\uparrow$ Electronic supplementary information (ESI) available: Synthesis and characterization of the studied molecules and required precursors. NMR, UV, and fluorescence spectra, titrations, control experiments, and detailed procedures for cell uptake and co-staining experiments. See DOI: $10.1039 / \mathrm{c} 3 \mathrm{sc} 53317 \mathrm{~d}$ of organometallic catalysis in synthetic chemistry, metal-based catalytic reactions have largely been overlooked in biological settings. ${ }^{6}$ While applying organometallic catalysis in aqueous media is not straightforward, several relevant metal-catalyzed reactions have been successfully used in biocompatible solvents, and even in cells, ${ }^{7}$ and it is foreseeable that the next few years will bring a rapid increase in the use of metal catalysis in biological environments. Particularly relevant in this area is the seminal work by E. Meggers and coworkers, who have demonstrated that ruthenium catalysts, combined with thiophenol, can be used to uncage alloc-protected rhodamines in aqueous media ( $\left.\mathrm{MeOH} / \mathrm{H}_{2} \mathrm{O}, 95: 5\right)$, and even inside HeLa cells, without significantly influencing the cell viability. ${ }^{8}$

Owing to our recent demonstration that caging the amidinium groups of bisbenzamidines, or the amino groups of ethidium, with photolabile nitrobenzyl groups suppresses their DNA interaction, ${ }^{4}$ we wondered whether simple alloc-protecting<smiles>CC(N)(COc1ccc(C(=N)N)cc1)C(=N)Oc1ccc(C(=N)N)cc1</smiles><smiles>N=C(N)c1ccc(NCc2cccc(CNc3ccc(C(N)=[NH2+])cc3)c2)cc1</smiles><smiles>N=C(N)c1ccc2cc(-c3ccc(C(N)=[NH2+])cc3)[nH]c2c1</smiles>

Fig. 1 Structure of selected DNA binders: pentamidine (1), propamidine (2), phenyl azapentamidine (3), DAPI (4) ethidium bromide (5). 
groups might also prevent DNA binding, which would raise the possibility of using metal- $\pi$-allyl chemistry for catalytic uncaging.

Herein we demonstrate the viability of this temporary allylcarbamate protecting approach for controlling the DNA binding of representative minor groove binders, such as bisbenzamidines, (3 and 4, Fig. 1), and of classic intercalators, like ethidium bromide (5, Fig. 1). Importantly, we also show that the uncaging reaction can be efficiently performed in living cells and that the redistribution of the released dyes can be monitored by fluorescence microscopy. This work represents the first demonstration of the use of metal catalysis to trigger DNA binding events in live cells.

\section{Results and discussion}

\section{Synthesis and in vitro fluorescence studies of protected derivatives of 3}

Bisbenzamidines like pentamidine (1) or propamidine (2) are structurally simple DNA binders that show good stability, sequence selectivity, and excellent internalization properties in a variety of cell lines. ${ }^{9}$ Although rather toxic, pentamidine and some of its derivatives are being used for the treatment of Pneumocystis carinii, Leishmaniasis or early-phase African sleeping sickness, among other diseases. ${ }^{10}$ Their mode of action is attributed to their ability to interact with the A/T-rich mitochondrial DNA of the parasites. ${ }^{11}$ We have recently shown that substitution of the oxygen atom of classic bis-benzamidines by a nitrogen generates aza derivatives, such as phenyl aza-pentamidine 3, with DNA-dependent fluorescent properties. ${ }^{12}$ These derivatives can be easily synthesized in a single step by reductive amination of commercial dialdehydes. ${ }^{13}$ The fluorogenic properties of these molecules resemble those of other DNA binders that are widely used as fluorescent stains, such as the blue nuclear stain DAPI (4' ${ }^{\prime}$ 6-diamidino-2-phenylindole, 4; Fig. 1) or ethidium bromide (5, Fig. 1). ${ }^{14}$

Installation of the alloc protecting groups in the aza-pentamidine 3 was readily accomplished by reaction with allyl chloroformate in the presence of $\mathrm{NaOH}$ in $\mathrm{H}_{2} \mathrm{O} / \mathrm{THF}(85 \%$ yield). The resulting dialloc protected derivative (C) 3 displays a relatively weak fluorescence intensity and slightly red-shifted emission in comparison to 3. As expected, while incubation of 3 with a hairpin oligonucleotide featuring an A/T-rich site $(h$-A3 - T3) leads to a large increase in its fluorescence emission upon irradiation at $320 \mathrm{~nm}$, C) 3 displays only a very modest emission intensity enhancement under the same conditions (Fig. 2).

Titration of $\odot 3$ with the oligonucleotide $h$-A3 $\cdot \mathbf{T} 3$ allowed us to calculate an apparent dissociation constant of $\approx 21 \mu \mathrm{M}$, which is over 30 times weaker than that exhibited by 3 for this same oligo $\left(K_{\mathrm{d}}[3] \approx 0.7 \mu \mathrm{M}\right) \cdot{ }^{13}$ The lower DNA affinity of the alloc-protected $\odot 3$ with respect to 3 can be attributed to the loss of the electrostatic and hydrogen bonding interactions of the amidinium groups in the caged derivative. ${ }^{15}$ This hypothesis is consistent with the results obtained with the analogous bisbenzamidine bis-allyl derivative 6, which, in contrast to @3, displays comparable binding affinity to that of the unprotected

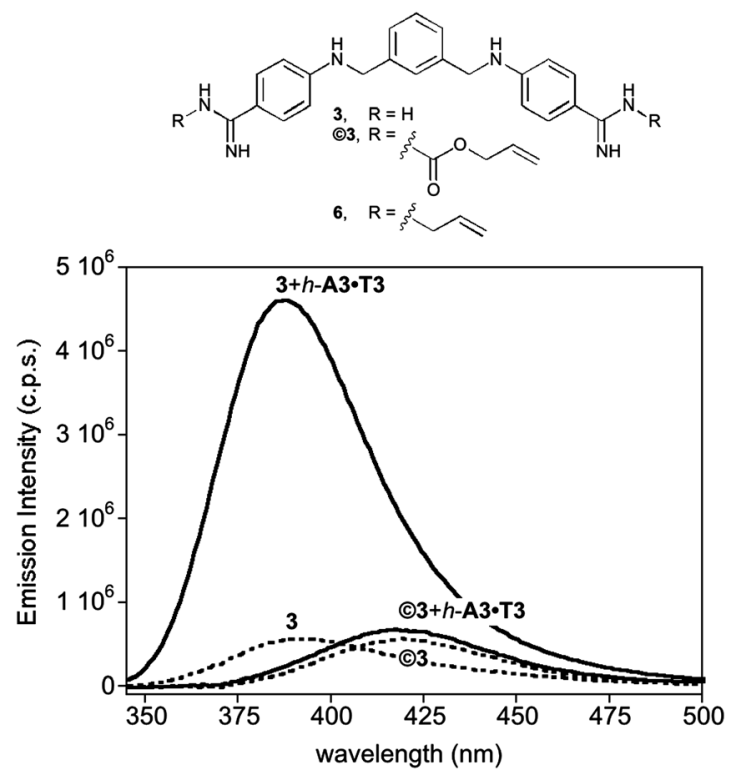

Fig. 2 Top: Structures of the alloc (@3), and allyl (6) protected derivatives of bisbenzamidine 3. Bottom: fluorescence emission of $5 \mu \mathrm{M}$ solutions of 3 and $\odot 3$ in Tris $-\mathrm{HCl} 20 \mathrm{mM}, 100 \mathrm{mM} \mathrm{NaCl}, \mathrm{pH} 7.5$ (dashed lines), and in the presence of 1 equiv. of $h-A 3 \cdot T 3$ (solid lines). h-A3-T3: 5'-GGC-AAATT-CAGTTाTCTG-AAATT-GCC-3'.

amidinium derivative $3\left(K_{\mathrm{d}}[6] \approx 0.5 \mu \mathrm{M}\right.$, see $\left.\mathrm{ESI} \dagger\right)$. As expected, (C) 3 also shows a very small increase in its emission intensity upon incubation with a G/C-rich oligonucleotide (see the ESI $\dagger$ ).

\section{Catalytic uncaging}

The deprotection reaction was first carried out by treatment of (C) 3 with thiophenol (5 equiv.) and $10 \%$ of ruthenium catalyst $\mathrm{RuCp}^{*}(\mathrm{COD}) \mathrm{Cl}([\mathrm{Ru}])$, at room temperature (rt) in $\mathrm{MeOH} / \mathrm{H}_{2} \mathrm{O}$ (95:5). High-performance liquid chromatography (HPLC) analysis of the reaction mixture after 20 min barely shows any starting material and the major peak corresponds to the parent bisbenzamidine 3 . Importantly, the reaction can also be efficiently carried out in more biologically relevant media (phosphate buffer $100 \mathrm{mM}, \mathrm{pH} 7.5$, and 10\% DMSO), although, under these conditions, after 20 min we still observe a minor amount of the mono-protected product m-@3 (Fig. 3). Continuing the reaction for a longer time did not produce a significant change in the proportion of the products $(85: 15)$.

The deprotection reaction could also be carried out with Pd catalysts using standard conditions for alloc removal. ${ }^{\mathbf{1 6}}$ Treatment of $\mathrm{C} 3$ with $\mathrm{Pd}(\mathrm{OAc})_{2}, \mathrm{~N}$-methyl morpholine, $\mathrm{PPh}_{3}$ and $\mathrm{PhSiH}_{3}$ in $100 \mathrm{mM}$ phosphate buffer $\mathrm{pH}$ 7.5, and 10\% DMSO, thus led to an almost quantitative conversion to 3 after 5 min; as expected, this deprotection did not proceed in the absence of the additives (see the $\mathrm{ESI}_{\dagger} \dagger$ ).

The Ru-catalyzed deprotection also takes place in the presence of calf thymus DNA (ct-DNA), although in this case after 20 min at rt we observed the formation of a $15: 45: 40$ mixture of the free (3), monoprotected (m-@3) and fully protected (@3) products, respectively (see the ESI $\dagger$ ). Given that the deprotection reactions generate different amounts of the 

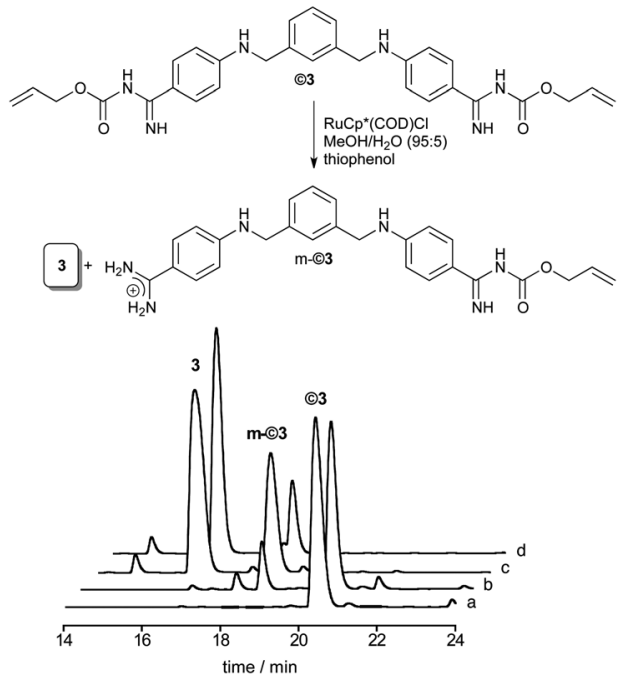

Fig. 3 Top: catalytic deprotection in phosphate buffer and 10\% DMSO. Bottom: HPLC trace of the uncaging reaction in phosphate

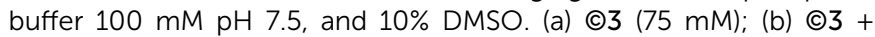
$\mathrm{PhSH}$ (325 mM); (c) @3 + PhSH + [Ru] (10\%), t= $1 \mathrm{~min}$; (d) $\odot 3+\mathrm{PhSH}+$ $[\mathrm{Ru}], t=20 \mathrm{~min}$.

monoprotected derivative m-@3, we studied its DNA binding properties. Unsurprisingly, titration of $\mathbf{m}-\mathrm{C} 3$ with $h-\mathbf{A} 3 \cdot \mathbf{T} 3$ revealed that this compound binds to the DNA with an intermediate affinity to that of the bis-alloc-protected product (C3 and the parent unprotected molecule $3\left(K_{\mathrm{d}}[\mathrm{m}-\odot 3] \approx 6.0 \mu \mathrm{M}\right.$, see the ESI $\dagger$ ).

\section{Deprotection and DNA binding studies of DAPI and ethidium derivatives}

As with (03, the bis-alloc DAPI derivative (C4 was readily obtained in good yield by treatment of $\mathbf{4}$ with allyl chloroformate and $\mathrm{Et}_{3} \mathrm{~N}$ in DMSO. In contrast to DAPI, (C4 displays a weak intrinsic fluorescence, but experienced a comparatively lower increase in emission when mixed with the $h$-A2 $\cdot \mathbf{T} 2$ hairpin oligonucleotide (Fig. 4). Steady state fluorescence titration of $\odot 4$ with this hairpin oligo revealed a $K_{\mathrm{d}}[\odot 4] \approx 0.41$ $\mu \mathrm{M}$, which represents an affinity more than 40 times weaker than that of DAPI $\left(K_{\mathrm{D}}[4] \leq 10 \mathrm{nM}\right) .{ }^{17}$ Likewise, as observed previously with 3 , inhibition of the DNA binding required the protection of both amidinium groups, since the single protected DAPI still exhibited significant DNA binding $\left(K_{\mathrm{d}}[\mathbf{m}-\mathrm{C})\right]$ $\approx 49 \mathrm{nM}$, see the $\mathrm{ESI} \dagger$ ).

The Ru-catalyzed uncaging of (C4 was faster and more efficient than that of $\odot 3$. Treatment of $\odot 4$ ( $25 \mathrm{mM})$ with thiophenol (5 equiv.) and $10 \%$ of the ruthenium catalyst [Ru], in $100 \mathrm{mM}$ phosphate buffer pH 7.5 and 10\% DMSO in the presence of ctDNA thus led to the desired parent compound 4 after only $5 \mathrm{~min}$ at rt (clean conversion by HPLC).

Finally, the catalytic uncaging strategy was also tested with ethidium bromide (5), a classic intercalator that is widely used for DNA and RNA staining. ${ }^{\mathbf{1 4}}$ Commercially available ethidium bromide (5) reacted efficiently with allyl chloroformate in DIEA/ DMF to yield the desired dialloc derivative @5 as a bright yellow solid (yield $\approx 58 \%$ ). Remarkably, in contrast to the parent ethidium, the biscarbamate $@ 5$ is highly fluorescent in aqueous solution in the absence of DNA, displaying a maximum emission wavelength at $510 \mathrm{~nm}$ (Fig. 5). While the addition of ct-DNA to ethidium induces a significant increase in its fluorescence emission at $595 \mathrm{~nm}$, addition of ct-DNA to the bis-caged ethidium $\odot 5$ leads to a decrease in its emission. ${ }^{18}$ As in the case of the minor groove binders discussed previously, the caged derivative displayed weaker DNA binding than the parent

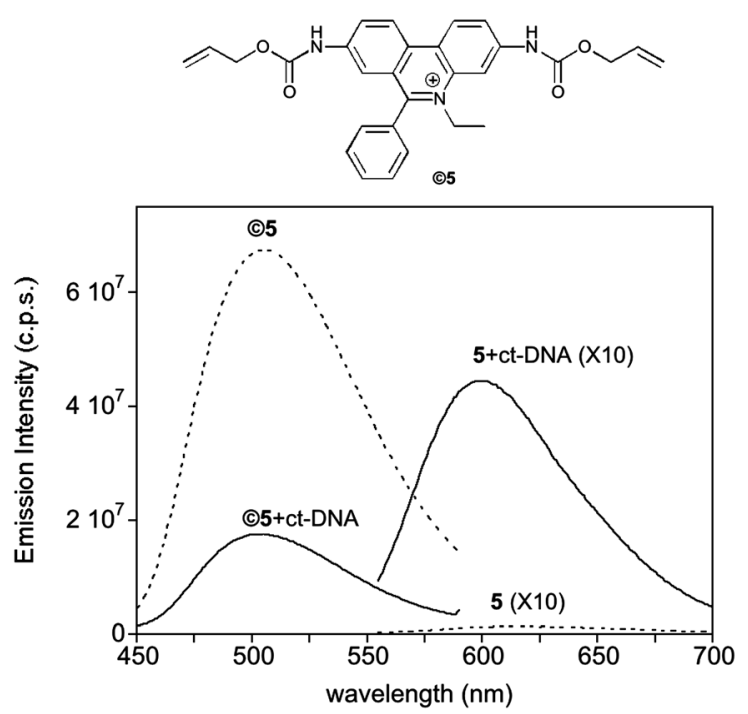

Fig. 5 Top: Structure of @5. Bottom: fluorescence emission spectra of $1 \mu \mathrm{M} 5$ and $\odot 5$ (dashed lines), and spectra of both compounds in the presence of $0.3 \mathrm{mg} \mathrm{mL}^{-1}$ of ct-DNA (solid lines). Spectra of 5 and of 5 in the presence of ct-DNA are represented multiplied by a factor of 10 for comparison. $\lambda_{\text {exc }} 5=545 \mathrm{~nm}, \lambda_{\text {exc }} \odot 5=300 \mathrm{~nm}$. 
ethidium: a nearly 20 -fold decrease in affinity for $h$-AGA (see the ESI $\dagger$ ).

With regard to the catalytic uncaging, treatment of (C5 (50 $\mathrm{mM}$ ) with thiophenol (5 equiv.) and $10 \%$ of $[\mathrm{Ru}]$ in phosphate buffer $100 \mathrm{mM}$ pH 7.5 and 10\% DMSO at rt in the presence of ct-DNA led to the expected uncaged products, although the reaction is slower than in the case of (C). HPLC of the reaction mixture after $20 \mathrm{~min}$ showed the formation of monouncaged derivatives, however, after $1 \mathrm{~h}$ most of the starting material had been transformed into the desired fully deprotected product (5). Interestingly, since the absorption of the protected derivative (@5) is different to that of the parent ethidium, the reaction progress can be monitored by observing changes in the solution color (inset in Fig. 6). Competitive titrations with 5 showed that the monoprotected ethidium derivatives also bind DNA, although with weaker affinity than the parent ethidium (see the ESI $\dagger$ ).

\section{Uncaging experiments in living cells}

The above results validate the attachment of alloc appendages as an efficient strategy to considerably inhibit the DNA binding of three different types of small DNA-binding agents, and confirm the viability of metal-catalyzed removal of the caging group under aqueous (and hypothetically biocompatible) conditions. We therefore explored the possibility of performing the catalytic de-allylation process to induce DNA binding in cellular settings. We focused our efforts on the study of DAPI and ethidium derivatives, because their cellular distribution might be easily monitored by fluorescence microscopy, thanks to the intrinsic fluorescence of the protected dyes and the characteristic emission pattern of the parent dyes when bound to the DNA (Fig. 4 and 5). Chicken embryo fibroblast (CEF) cells were thus incubated with $\odot 4(2.5 \mu \mathrm{M})$ in serum-free medium for $30 \mathrm{~min}$ at $37^{\circ} \mathrm{C}$. The medium was then removed and the wells were rinsed twice with PBS to remove excess of (C4. Fluorescence microscopy (excitation filter 360-370 nm/emission filter $420 \mathrm{~nm}$ ) showed blue staining of the whole cell, indicating that the alloc-protected DAPI (@4) is evenly distributed in the cells

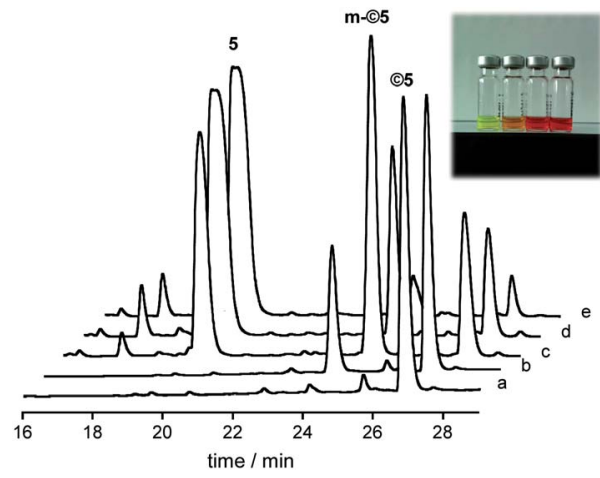

Fig. 6 HPLC trace of the deprotection reaction of (95. (a) (5) in buffer (50 mM); (b) @5 + PhSH (250 mM) + ct-DNA (0.1 mg ml $\left.{ }^{-1}\right)$; (c) @5 + $\mathrm{PhSH}+\mathrm{ct}-\mathrm{DNA}+\mathrm{Ru}(10 \%) t=0$; (d) $\odot 5+\mathrm{PhSH}+\mathrm{ct}-\mathrm{DNA}+\mathrm{Ru} t=$ 20 min; (e) $\odot 5+\mathrm{PhSH}+\mathrm{ct}-\mathrm{DNA}+\mathrm{Ru} t=1 \mathrm{~h}$. Inset: picture (left to right) of the aliquots $\mathrm{a}, \mathrm{b}, \mathrm{c}$ and $\mathrm{e}$.
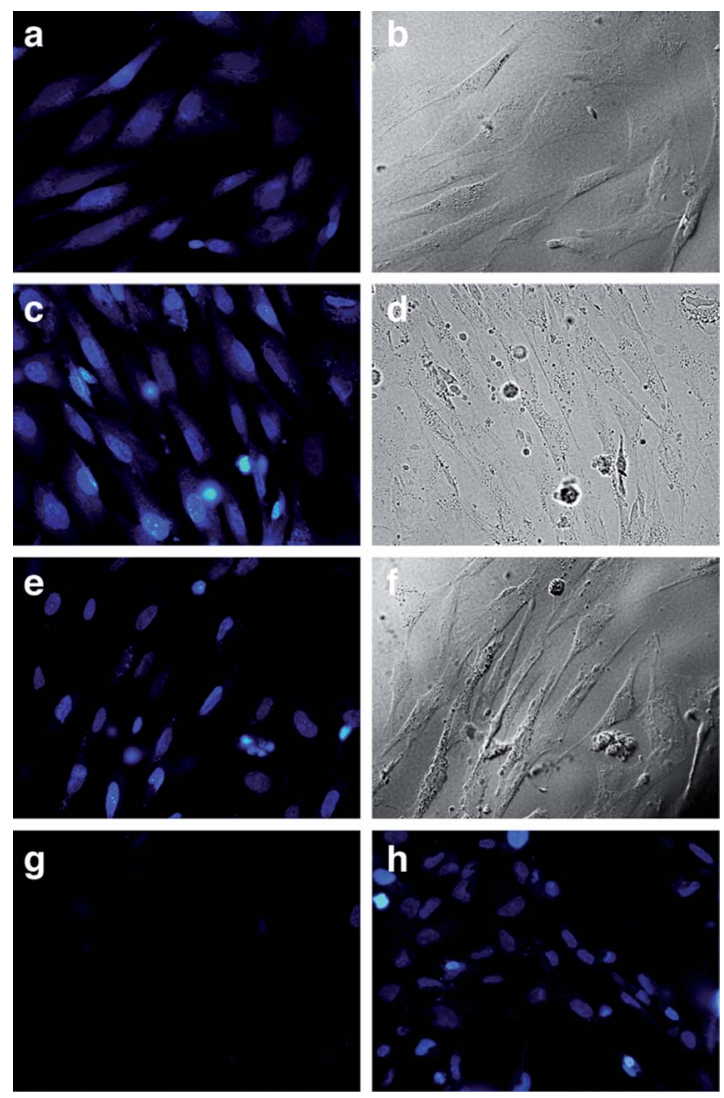

Fig. 7 Ru-catalyzed deprotection of $2.5 \mu \mathrm{M} \odot 4$ in CEF cells: (a) @ 4, 30 min at $37^{\circ} \mathrm{C}$, blue channel; (b) ๑4, 30 min at $37^{\circ} \mathrm{C}$, brightfield; (c) ๑4 treated with $2.5 \mu \mathrm{M}[\mathrm{Ru}]$ and $100 \mu \mathrm{M} \mathrm{PhSH}, 8 \mathrm{~min}$, blue channel; (d) (c) 4 treated with $2.5 \mu \mathrm{M}[\mathrm{Ru}]$ and $100 \mu \mathrm{M} \mathrm{PhSH}, 8 \mathrm{~min}$, brightfield; (e) (๑4 treated $20 \mathrm{~min}$ with $2.5 \mu \mathrm{M}[\mathrm{Ru}]$ and $100 \mu \mathrm{M} \mathrm{PhSH}, 20 \mathrm{~min}$, blue channel; (f) @ 4 treated 20 min with $2.5 \mu \mathrm{M}$ [Ru] and $100 \mu \mathrm{M} \mathrm{PhSH}$, $20 \mathrm{~min}$, brightfield. (g) control with $2.5 \mu \mathrm{M} 4$ after $30 \mathrm{~min}$ at $37^{\circ} \mathrm{C}$, blue channel; (h) control with $15 \mu \mathrm{M} 4$ after $30 \mathrm{~min}, 37^{\circ} \mathrm{C}$, blue channel. Blue channel fluorescence microscopy settings: excitation filter 360$370 \mathrm{~nm}$, emission filter $420 \mathrm{~nm}$ and dichromatic mirror $400 \mathrm{~nm}$.

(Fig. 7a). After washing twice with PBS, cells were resuspended in media and treated with the ruthenium catalyst [Ru] dissolved in DMSO $(2.5 \mu \mathrm{M})$ and PhSH $(100 \mu \mathrm{M})$ at $37^{\circ} \mathrm{C}$, and observed under the microscope at increasing incubation times ( 8 and 20 minutes). After $8 \mathrm{~min}$ (Fig. 7c), there is a relatively more intense nuclear emission, but also blue staining of the cytoplasm, but after $20 \mathrm{~min}$ the cells show the typical nuclear staining of DAPI (Fig. 7e). The redistribution of the stain is consistent with the expected deprotection reaction and the liberation of 4. Interestingly, a control experiment in which cells were incubated with $2.5 \mu \mathrm{M}$ of DAPI resulted in very weak emission from the cells (Fig. 7g), and the use of higher concentrations of DAPI (up to $15 \mu \mathrm{M}$ ) was required to see a clear staining (Fig. 7h). This enhanced staining efficiency resulting from the uncaging of $\mathrm{C} 4$, in comparison with that directly obtained with DAPI (Fig. 7e and g), suggests that the diallocderivative (C4 is internalized very efficiently and converted into DAPI inside the cells, otherwise the staining intensity should have been similar in both cases. Moreover, control experiments 
demonstrated that, before the addition of the ruthenium catalyst, the medium shows almost no fluorescence, suggesting that (C) 4 does not leak out of the cell significantly (see the ESI $\dagger$ ). While further studies are needed, these results provide support for an intracellular uncaging reaction.

In consonance with previous findings by Meggers et al. ${ }^{8}$ we found that both the metal catalyst and the thiophenol additive are required to obtain an efficient cellular uncaging (see the ESI $\dagger$ ). Importantly, cytotoxicity experiments using trypan blue, ${ }^{19}$ revealed that cells treated with $20 \mu \mathrm{M}$ of $[\mathrm{Ru}]$ and $100 \mu \mathrm{M}$ $\mathrm{PhSH}$ display a fairly similar phenotypic viability to untreated cultures (see the ESI $\dagger$ ). Moreover, comparative staining with propidium iodide $(20 \mu \mathrm{M})$ showed that treatment of CEF cells with the standard reaction cocktail does not apparently disrupt the integrity of cell membranes (see the ESI $\dagger$ ). As expected, the uncaging process could be achieved in other cell types, such as Vero cells from African green monkey kidney. Consistent with the previous results with CEF cells, incubation of Vero cells with protected DAPI (@4) leads to a more or less homogeneous staining, with the dye evenly distributed between the cytoplasm and the cell nuclei (Fig. 8a). Addition of the reagents $(2.5 \mu \mathrm{M}$ $[\mathrm{Ru}]$ and $100 \mu \mathrm{M} \mathrm{PhSH}$ ) led to a clear redistribution of the emission into the cell nuclei (Fig. 8c), as expected for release of the uncaged DAPI and its sticking to nuclear DNA.

With regard to the uncaging of ethidium, the distinctive emission pattern of the protected and unprotected derivatives allowed a detailed monitoring of the uncaging process. (5) thus gives a clear green staining of the cells (excitation filter 460$490 \mathrm{~nm} / \mathrm{emission}$ filter $520 \mathrm{~nm}$ ), with a preferential accumulation of the caged dye in cytoplasmatic structures (Fig. 9a). As expected from the fluorescence spectrum (Fig. 5), no emission was observed in the red channel (excitation filter $530-550 \mathrm{~nm} /$ emission filter $590 \mathrm{~nm})$. Treatment of the cells with [Ru] (20 $\mu \mathrm{M})$ and $\mathrm{PhSH}(100 \mu \mathrm{M})$ for $20 \mathrm{~min}$ led to the characteristic staining of ethidium bromide in the red channel, with the emission mainly concentrated in the nuclei and nucleoli (Fig. 9f), while almost no signal was observed in the green channel (Fig. 9d), suggesting that the uncaging had been very efficient.
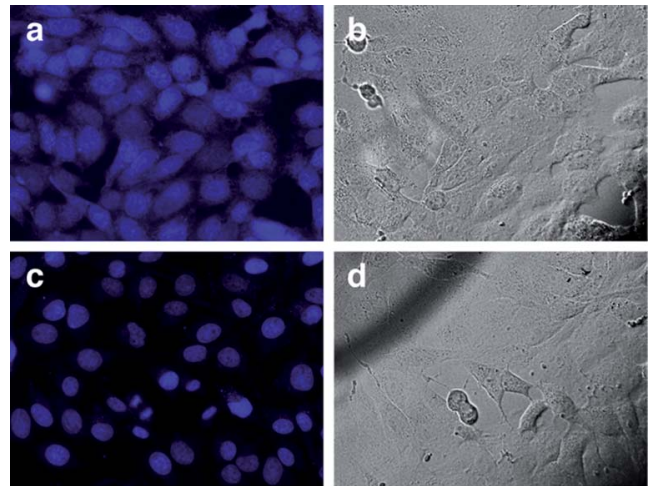

Fig. 8 Ru-catalyzed deprotection of $2.5 \mu \mathrm{M}$ of $\odot 4$ in Vero cells. Top row: $\odot 4,30 \mathrm{~min}$ at $37^{\circ} \mathrm{C}$ (a) blue channel; (b) brightfield. Bottom row: (c) 4 with $2.5 \mu \mathrm{M}[\mathrm{Ru}]$ and $100 \mu \mathrm{M} \mathrm{PhSH}, 20 \mathrm{~min}$; (c) blue channel; (d) brightfield.
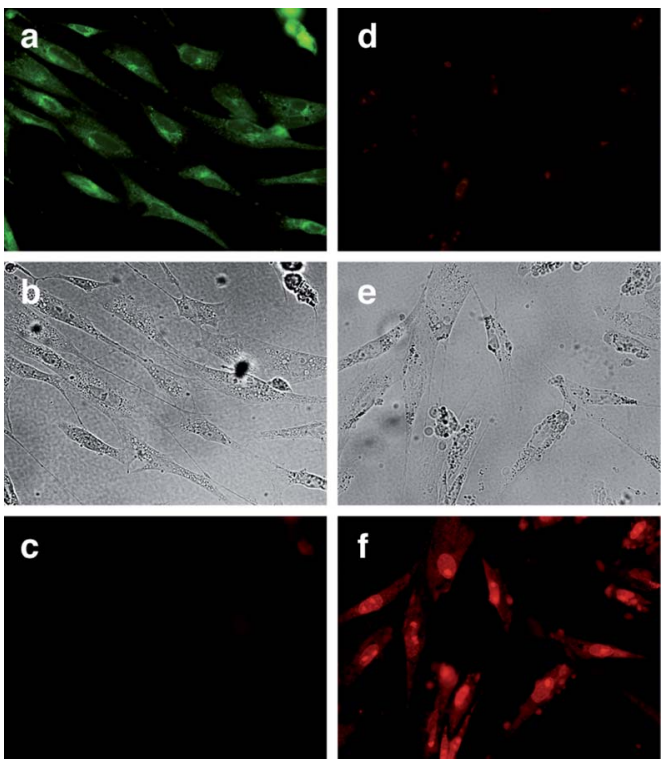

Fig. 9 Ru-catalyzed deprotection of $10 \mu \mathrm{M}$ (05 in CEF cells. Left column: ( 5,30 min at $37^{\circ} \mathrm{C}$; (a) green channel; (b) brightfield; (c) red channel. Right column: @5 incubated with $20 \mu \mathrm{M}$ [Ru] and $100 \mu \mathrm{M}$ PhSH, 20 min; (d) green channel; (e) brightfield; (f) red channel. Fluorescence microscopy settings for green channel: filter 530$550 \mathrm{~nm}$, emission filter $590 \mathrm{~nm}$ and dichromatic mirror $570 \mathrm{~nm}$; and for red channel: filter 530-550 nm, emission filter $590 \mathrm{~nm}$ and dichromatic mirror $570 \mathrm{~nm}$.

\section{Biological activity}

The above results demonstrate that caging key functional groups of DNA binding agents, even with simple alloc moieties, results in a significant decrease in their DNA affinity. A potential biomedical application of this chemistry required the demonstration that such a decrease in DNA binding is also associated with a decreased biological effect. We therefore checked the activity of the protected (@3) and unprotected bis-benzamidines (3) against cancer cell lines. Interestingly, in the cisplatinresistant $\mathrm{A} 2780$ cell line (human ovarian carcinoma), the inhibitory effect of the caged derivative was more than ten times lower than that of the parent aza pentamidine $\left(\mathrm{IC}_{50}[\mathrm{C} 3] \approx\right.$ $\left.5.0 \mu \mathrm{M}, \mathrm{IC}_{50}[3] \approx 0.4 \mu \mathrm{M}\right)$, which in turn had a stronger inhibitory effect than cisplatin $\left(\mathrm{IC}_{50}\right.$ [cisplatin] $\left.\approx 7.4 \mu \mathrm{M}\right)$. Similar effects of the alloc caging were also observed with the related $\mathrm{A} 2780 \mathrm{cDDP}$ cell line $\left(\mathrm{IC}_{50}[\mathrm{C} 3] \approx 5.1 \mu \mathrm{M}, \mathrm{IC}_{50}[3] \approx 0.9\right.$, $\mathrm{IC}_{50}$ [cisplatin] $\approx 0.8$ ). The ruthenium catalyst had negligible inhibitory effect by itself with an $\mathrm{IC}_{50} \geq 45 \mu \mathrm{M}^{20}$ These results open the door to future pro-drug strategies that rely on the combination of caged precursors and an appropriate metal complex for controlled catalytic uncaging.

\section{Conclusions}

In conclusion, we have demonstrated that installing simple allylcarbamate groups in the key positions of several DNA binders not only decreases their interaction with DNA, but also modulates their spectroscopic properties and cellular location. 
In particular, we have demonstrated that the bis alloc-protected derivatives of DAPI or ethidium bromide are weaker DNA binders than the parent compounds, which can be efficiently regenerated in aqueous buffers, and even in cellular environments, by reaction with a ruthenium catalytic system. Our results set the stage for future developments on metal-catalyzed activation of DNA-binding compounds in biological media.

\section{Acknowledgements}

We are thankful for the support given by the Spanish grants SAF2010-20822-C02, CTQ2012-31341, Consolider Ingenio 2010 CSD2007-00006, the Xunta de Galicia, GRC2010/12, GRC2013041, PGIDIT08CSA-047209PR, the ERDF and the European Research Council (Advanced Grant $\mathrm{N}^{\mathrm{a}}$ 340055). M. I. S. and C. P. thank the Spanish Ministry for their PhD fellowships. We also want to thank the molecular virology group headed by $\mathrm{Dr} \mathrm{J}$. Benavente and Dr J. Martínez Costas, and especially Rebeca Menaya Vargas, Zaira Afonso Puerta and Irene Lostalé Seijo (CIQUS).

\section{Notes and references}

1 (a) M. E. Vázquez, A. M. Caamaño and J. L. Mascareñas, Chem. Soc. Rev., 2003, 32, 338; (b) E. Pazos, J. Mosquera, M. E. Vázquez and J. L. Mascareñas, ChemBioChem, 2011, 12, 1958; (c) J. B. Chaires, Curr. Opin. Struct. Biol., 1998, 8, 314-320.

2 (a) P. B. Dervan and R. W. Bürli, Curr. Opin. Chem. Biol., 1999, 3, 688-693; (b) B. S. Reddy, S. M. Sondhi and J. W. Lown, Pharmacol. Ther., 1999, 84, 1-111; (c) S.-I. Sato, M. Hagihara, K. Sugimoto and T. Morii, Chem.-Eur. J., 2002, 8, 5066-5071; (d) M. E. Vázquez, A. M. Caamaño, J. Martínez-Costas, L. Castedo and J. L. Mascareñas, Angew. Chem., Int. Ed., 2001, 40, 4723; (e) O. Vazquez, M. E. Vázquez, J. B. Blanco, L. Castedo and J. L. Mascarenas, Angew. Chem., Int. Ed., 2007, 46, 68866890; (f) J. Bordello, M. I. Sánchez, M. E. Vázquez, J. L. Mascareñas, W. Al-Soufi and M. Novo, Angew. Chem., Int. Ed., 2012, 51, 7541-7544.

3 (a) S.-A. Morgan and G. A. Woolley, Photochem. Photobiol. Sci., 2010, 9, 1320-1326; (b) J. Andersson, S. Li, P. Lincoln and J. Andréasson, J. Am. Chem. Soc., 2008, 130, 1183611837; (c) S. Park, T. Bando, K.-I. Shinohara, S. Nishijima and H. Sugiyama, Bioconjugate Chem., 2011, 22, 120-124; (d) A. Nomura and A. Okamoto, Chem. Commun., 2009, 1906-1908; (e) M. L. Di Pietro, F. Puntoriero, F. Tuyéras, P. Ochsenbein, P. P. Lainé and S. Campagna, Chem. Commun., 2010, 46, 5169-5171; $(f)$ A. M. Caamaño, M. E. Vazquez, J. Martinez-Costas, L. Castedo and J. L. Mascareñas, Angew. Chem., Int. Ed., 2000, 39, 31043107; $(g)$ A. Jiménez, E. Pazos, B. Martínez-Albardonedo, J. L. Mascareñas and M. E. Vazquez, Angew. Chem., Int. Ed., 2012, 51, 8825-8829; (h) J. Mosquera, A. Jiménez, V. I. Dodero, M. E. Vázquez and J. L. Mascareñas, Nat. Commun., 2013, 4, 1874-1878.
4 (a) M. I. Sánchez, O. Vazquez, M. E. Vazquez and J. L. Mascareñas, Chem. Commun., 2011, 47, 11107-11109; (b) M. I. Sánchez, J. Martinez-Costas, F. Gonzalez, M. A. Bermudez, M. E. Vazquez and J. L. Mascareñas, ACS Chem. Biol., 2012, 7, 1276-1280.

5 J. Rautio, H. Kumpulainen, T. Heimbach, R. Oliyai, D. Oh, T. Järvinen and J. Savolainen, Nat. Rev. Drug Discovery, 2008, 7, 255-270.

6 For a recent review see: P. K. Sasmal, C. N. Streu and E. Meggers, Chem. Commun., 2013, 49, 1581-1587.

7 (a) R. M. Yusop, A. Unciti-Broceta, E. M. V. Johansson, R. M. Sánchez-Martín and M. Bradley, Nat. Chem., 2011, 3, 239-243; (b) P. K. Sasmal, S. Carregal-Romero, A. A. Han, C. N. Streu, Z. Lin, K. Namikawa, S. L. Elliott, R. W. Köster, W. J. Parak and E. Meggers, ChemBioChem, 2012, 13, 11161120; (c) N. Li, R. K. V. Lim, S. Edwardraja and Q. Lin, J. Am. Chem. Soc., 2011, 133, 15316-15319; (d) Y. A. Lin, J. M. Chalker and B. G. Davis, J. Am. Chem. Soc., 2010, 132, 16805-16811; (e) C. D. Spicer and B. G. Davis, Chem. Commun., 2011, 47, 1698-1700; (f) K. L. Haas and K. J. Franz, Chem. Rev., 2009, 109, 4921-4960; $(g)$ M. Patra and G. Gasser, ChemBioChem, 2012, 13, 1232-1252.

8 C. Streu and E. Meggers, Angew. Chem., Int. Ed., 2006, 45, 5645-5648.

9 (a) R. R. Tidwell and D. W. Boykin, DNA and RNA Binders: From Small Molecules to Drugs, ed. M. Demeunynck, C. Bailly and W. D. Wilson, Wiley-VCH, Weinheim, 2003, vol. 2, pp. 414-460; (b) A. Lansiaux, F. Tanious, Z. Mishal, L. Dassonneville, A. Kumar, C. E. Stephens, Q. Hu, W. D. Wilson, D. W. Boykin and C. Bailly, Cancer Res., 2002, 62, 7219-7229.

10 (a) W. D. Wilson, F. A. Tanious, A. M. Mathis, D. Tevis, J. E. Hall and D. W. Boykin, Biochimie, 2008, 90, 999-1014; (b) A. Mayence, A. Pietka, M. S. Collins, M. T. Cushion, B. L. Tekwani, T. L. Huang and J. J. Vanden Eynde, Bioorg. Med. Chem. Lett., 2008, 18, 2658-2661.

11 W. D. Wilson, F. A. Tanious, A. M. Mathis, D. Tevis, J. E. Hall and D. W. Boykin, Biochimie, 2008, 90, 999-1014.

12 O. Vazquez, M. I. Sánchez, J. Martinez-Costas, M. E. Vazquez and J. L. Mascareñas, Org. Lett., 2010, 12, 216-219; O. Vázquez, M. I. Sánchez, M. E. Vázquez and J. L. Mascareñas, Chem. Commun., 2010, 46, 5518-5520.

13 M. I. Sánchez, O. Vazquez, J. Martinez-Costas, M. E. Vazquez and J. L. Mascareñas, Chem. Sci., 2012, 3, 2383-2387.

14 (a) J. B. LePecq and C. Paoletti, J. Mol. Biol., 1967, 27, 87-106; (b) M. J. Waring, J. Mol. Biol., 1965, 13, 269-282.

15 (a) M. R. Conte, T. C. Jenkins and A. N. Lane, Eur. J. Biochem., 1995, 229, 433-444; (b) C. M. Nunn and S. Neidle, J. Med. Chem., 1995, 38, 2317-2325; (c) C. M. Nunn, T. C. Jenkins and S. Neidle, Biochemistry, 1993, 32, 13838-13843.

16 (a) P. Gomez-Martinez, M. Dessolin, F. Guibe and F. Albericio, J. Chem. Soc., Perkin Trans. 1, 1999, 2871-2874; (b) P. G. M. Wuts and T. W. Greene, in Greene's Protective Groups in Organic Synthesis, John Wileyand Sons, New York, 4th edn, 2006.

17 F. G. Loontiens, L. W. McLaughlin, S. Diekmann and R. M. Clegg, Biochemistry, 1991, 30, 182-189. 
18 These spectroscopic changes are consistent with previous reports in related modifications: (a) N. W. Luedtke, Q. Liu and Y. Tor, Chem.-Eur. J., 2005, 11, 495-508; (b) N. W. Luedtke, Q. Liu and Y. Tor, Bioorg. Med. Chem., 2003, 11, 5235-5247.
19 K. Anestål and E. S. J. Arnér, J. Biol. Chem., 2003, 278, 1596615972.

20 The incubation time required for uncaging $(30 \mathrm{~min})$ is much shorter than that used in the growth inhibitory studies (96 h). 